\section{市街化調整区域における開発許 可条例に基づく土地利用マネジ メントに関する研究}

一兵庫県加古川市における特別指定区 域制度の運用を事例として一

\section{A STUDY ON LAND-USE MANAGEMENT BASED ON DEVELOPMENT PERMISSION ORDINANCE IN URBANIZATION CONTROLAREA}

- A case study of "Special designated district system" in Kakogawa city -

\section{白井高行}

浅野純一郎—— $* 2$

キーワード :

土地利用計画，市街化調整区域，特別指定区域制度，加古川市, 都市計画法第 34 条 12 号

Keywords:

Land-use plan, Urbanization control area, Special designated district, Kakogawa city, Article 34-12 of city planning law
Takayuki SHIRAI — $* 1 \quad$ Junichiro ASANO - $* 2$

This study clarifies the effect of the planning and operation, focusing on community development council of Kakogawa city, which is one of the municipalities that are recognized unique in the practical use of the Special Designated District System. A case study for an individual district has implemented the system contents changes specified the system conditions, contents, and operating achievements as well.

\section{1.はじめに}

\section{1-1. 研究の目的と背景}

地方都市では, 高齢化が進む中で, 市街化が拡散して低密度な市 街地を形成しているとともに,「コンパクトシティ・プラス・ネット ワーク」の考え方でまちづくりを行うことが重要と考えられ，2014 年の都市再生特別措置法改正により,「立地適正化計画」が創設され た。立地適正化計画の策定が進む中，ますます，都市郊外部の土地 利用コントロールの多様化や柔軟な対応が可能となる開発許可制度 のあり方，とりわけ，市街化調整区域（以下，調整区域）では厳し い開発制限による人口減少や高齢化等により, 郊外スプロールの防 止力とそこでの開発許可制度との弾力的な運用が求められる。2000 年の都市計画法改正により, 開発圧力の格差や開発内容の多様化に 備える代表的方法の一つが開発許可条例による開発規制の弾力化で あり，その用い方の工夫と高度化は都市郊外部の土地利用コントロ 一ルの多様化の可能性とも関係が密接である。兵庫県が施行する特 別指定区域制度は, 2002 年に都市計画法第 34 条 12 号を根拠として 創設され，調整区域に土地利用計画を取り入れながら，開発規制を 緩和する点で規制の弾力化について先進事例であるが, 兵庫県加古 川市では, 2006 年に兵庫県の制度を基に, 対象区域や区域メニュー 及びまちづくり協議会 (1)を中心とする区域指定の発意, 運用に独自 性が認められる事例である。また，立地適正化計画の創設等の都市 計画を取り巻く環境の変化とともに, 兵庫県都市計画区域マスター プラン (東播) 改定や加古川市まち・ひと・しごと創生総合戦略等 を踏まえ, 現在, 都市計画マスタープラン（以下，都市マス）の改 定作業を行っている状況である。

既往研究をみると, 兵庫県における特別指定区域制度の策定経緯 から適用時の実態を明らかにした研究 ${ }^{1 \sim 2)}$, 兵庫県小野市の運用実
態等から制度の効果と課題を明らかにした研究 ${ }^{3)}$, さらに, 兵庫県 加古川市の制度導入時における指定状況等を明らかにした研究 ${ }^{4)}$ が ある。しかし, 兵庫県の特別指定区域制度の見直し（2015 年 4 月 1 日条例改正) 後, 兵庫県並びに県内自治体の事例は無く, 兵庫県の 基準を用いた小野市では，市が素案を作成する区域指定の運用実態 を分析した研究である。また, 加古川市の制度導入時以降の運用実 態, 特に, 指定内容の変更等に基づく, 運用の効果を明らかにした 研究は見られず，そこに本研究の意義があると考える。

本研究では，加古川市の運用に独自性が認められる特別指定区域 制度（以下，田園まちづくり制度（計画）(2)）の内，まちづくり協 議会に着目し, 指定状況やその内容及び運用実態を明らかにすると ともに，指定内容の変更等を実施している地区についてケーススタ ディを行うことで, まちづくり協議会における運用と効果を考察す ることを目的とする。

\section{2. 研究の方法とフロー}

研究の方法は, HP で公開されている行政資料や加古川市都市計画 部都市計画課から提供頂いた田園まちづくり制度等に関わる各種資 料, 開発許可データ等に基づき分析を行った。また, 担当者へのヒ アリング調査（2016 年 2 月〜 7 月）や田園まちづくり制度に基づき 指定された地区において, 開発許可件数が多い地区や指定内容の変 更等を実施している地区に, 現地調査（2016 年 3 月）を行った。本 研究のフローとして，3 章では加古川市における調整区域の土地利 用方針や開発許可デー夕等の状況を定量的に把握し，都市郊外部の 土地利用や田園・集落環境の現況を明らかにする。また, 田園まち づくり計画の区域メニューを兵庫県との比較を通じてその特性を明 らかにする。4 章では, 田園まちづくり計画の指定地区の状況や地

\footnotetext{
豊橋技術科学大学大学院建築・都市システム学系 博士後期課程

( ( 4 4 1-8580 豊橋市天伯町字雲雀ヶ丘 1-1)

豊橋技術科学大学大学院建築・都市システム学系 教授・博士 (工学)
}

Ph.D. Candidate, Graduate School of Architecture and Civil Engineering, Faculty of Technology, Toyohashi Univ. of Technology

Prof., Dept. of Architecture and Civil Engineering, Faculty of Technology, Toyohashi Univ. of Technology, Dr. Eng. 
表 1 加古川市等における人口・面積の動向

\begin{tabular}{|c|c|c|c|c|c|c|c|c|c|c|c|c|c|c|c|c|}
\hline \multirow{3}{*}{ 自治体名 } & \multicolumn{8}{|c|}{ 市街化区域 } & \multicolumn{8}{|c|}{ 市街化調整区域 } \\
\hline & \multicolumn{2}{|c|}{ 面積(ha) } & 増減率 & \multirow{2}{*}{$\begin{array}{c}\text { 面積割合 } \\
※ 1\end{array}$} & \multicolumn{2}{|c|}{ 人口(千人) } & \multirow{2}{*}{\begin{tabular}{c|} 
増隇率 \\
$1980-2014$
\end{tabular}} & \multirow{2}{*}{$\begin{array}{c}\text { 人口割合※ } \\
1\end{array}$} & \multicolumn{2}{|c|}{ 面積(ha) } & \multirow{2}{*}{\begin{tabular}{|c|} 
増減率 \\
1980-2014 \\
\end{tabular}} & \multirow{2}{*}{$\begin{array}{l}\text { 面積割合 } \\
※ 2\end{array}$} & \multicolumn{2}{|c|}{ 人口(千人) } & \multirow{2}{*}{\begin{tabular}{|c|} 
増減率 \\
$1980-2014$
\end{tabular}} & \multirow{2}{*}{$\begin{array}{c}\text { 人口割合 } \\
※ 2\end{array}$} \\
\hline & 1980年 & 2014年 & \begin{tabular}{|l|}
$1980-2014$ \\
\end{tabular} & & 1980年 & 2014年 & & & 1980年 & 2014年 & & & 1980年 & 2014年 & & \\
\hline 兵庫県 & $64,878.0$ & $71,241.0$ & $4.7 \%$ & $26.7 \%$ & $3,963.0$ & $4,5,563.9$ & $7.0 \%$ & $91.8 \%$ & $181,431.0$ & $195,155.0$ & $3.6 \%$ & $73.3 \%$ & 452.3 & 405.1 & $-5.5 \%$ & $8.2 \%$ \\
\hline 加古川市 & $3,768.0$ & $4,016.0$ & $3.2 \%$ & $29.0 \%$ & 157.7 & 218.2 & $16.1 \%$ & $81.7 \%$ & \begin{tabular}{|l|}
$10,018.0$ \\
\end{tabular} & $9,835.0$ & $-0.9 \%$ & $71.0 \%$ & 51.6 & 48.9 & $-2.7 \%$ & $18.3 \%$ \\
\hline 明石市 & $3,782.0$ & $3,889.0$ & $1.4 \%$ & $79.0 \%$ & 245.9 & 284.6 & $7.3 \%$ & $97.8 \%$ & $1,187.0$ & $1,036.0$ & $-6.8 \%$ & $21.0 \%$ & 8.0 & 6.3 & $-11.9 \%$ & $2.2 \%$ \\
\hline 宝塚市 & $2,217.0$ & $2,608.0$ & $8.1 \%$ & $25.6 \%$ & 169.0 & 230.8 & $15.5 \%$ & $98.7 \%$ & $7,972.0$ & $7,581.0$ & $-2.5 \%$ & $74.4 \%$ & 12.5 & 3.0 & $-61.3 \%$ & $1.3 \%$ \\
\hline
\end{tabular}
県以外の3市では市域全てが都市計画区域。

区毎の許可実績等を把握する。また，まちづくり協議会による制度 の運用として, 田園まちづくり計画の指定内容の変更等について, 時期や内容及び背景, さらに, 変更後の運用実態について検証行い, 6 章ではこれらを踏まえ, 課題や効果を総括する。

\section{3. 加古川市の調整区域における開発管理区域}

加古川市は，兵庫県東播磨地域に位置する特例市である。市域は 13,851ha，全域が都市計画区域であり，市街化区域が 4, 016ha (29.0\%)，調整区域が 9, 835ha (71.0\%) の構成である。人口は 267.1 千人 (3)であり，市街化区域に 218.2 千人 (81.7\%)，調整区域に 48.9 千人 $(18.3 \%)$ となり, 兵庫県の調整区域人口比率の平均 $8.2 \%$, 他 特例市の明石市 $2.2 \%$ や宝塚市 $1.3 \%$, 全国平均の $11.0 \%$ (4) と比較し ても非常に高いことから，潜在的にみて調整区域における土地利用 整序に課題がある都市だと言える（表 1 ）。

加古川市は 5 市 2 町に囲まれており, ほぼ中央から西側に加古川 が位置し, 市街化区域は南部に集中しており, 市街地は隣接市町と 連胆している (図 1)。逆に市の北部には多数のため池や里山及び湖 が存在する中にある特徵的な集落地域が広がっており, 特に志方町, 平荘町, 上荘町, 八幡町の北部地域では, 人口減少が続き, 高齢化 率も約 25.5\%（市域全体では約 20.7\%） (5) に達する等，既存集落の 衰退が懸念されている。そこで, 次に記述する田園まちづくり計画 の対象区域は北部地域としている。

\section{3-1. 加古川市都市マスにおける調整区域の土地利用方針}

調整区域の土地利用方針は，開発管理区域に位置づけられるかど うかで対応が異なる。つまり，調整区域から加古川（河川，既存住 宅地区，集落地域整備事業地区を除いた区域が，開発管理区域であ る (表 2)。開発管理区域は, 田園環境保全地区, 沿道開発調整区域, 自然環境保全地区から構成され ており，都市マスの中で明示さ れている。土地利用の方針のそ の他と, 開発管理区域の中で, 都市計画法第 34 条 12 号による 田園まちづくり計画の指定区域 は, 田園環境保全地区と自然環 境保全地区に適用される。また， 沿道開発調整区域には, 都市計 画法第 34 条 10 号による地区計 画 (集落型・開発型・沿道型 が導入されている。

田園まちづくり制度は，2008 年 3 月に条例が制定されたが, 2012 年 4 月改正の都市マスでは, 2004 年の都市マスにおける, 開 発管理区域を踏襲し，開発管理

\begin{tabular}{|c|c|c|c|c|c|c|}
\hline \multicolumn{6}{|c|}{ 2012年「平成23年4月」 } & \multirow{2}{*}{$\begin{array}{l}\text { 2004年「平成16年4月」 } \\
\text { 農業環境を保全·育成し、農業体験の場としての活用を検 } \\
\text { 討する。 }\end{array}$} \\
\hline & \multirow{6}{*}{ 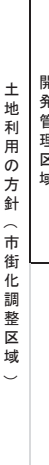 } & $\begin{array}{l}\text { 田園環境保 } \\
\text { 全地区 }\end{array}$ & 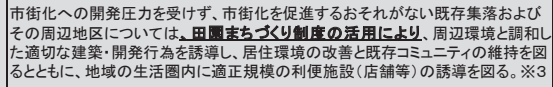 & \multirow{6}{*}{ 域 } & 田園環 & \\
\hline & & \multirow{2}{*}{\begin{tabular}{|l} 
汾道閏区発調 \\
自然環境保 \\
全地区
\end{tabular}} & 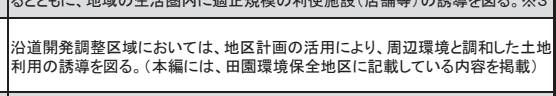 & & \begin{tabular}{|l} 
開発許容区 \\
域
\end{tabular} & $\begin{array}{l}\text { 既存集落·周辺地区は、周辺環境と調和した適切な建 } \\
\text { 筑·開發行為の誘導を图以、開発許容区域は、市街化区 } \\
\text { 域編入も検討する。 }\end{array}$ \\
\hline & & & 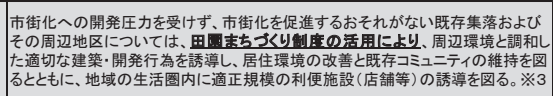 & & 自然環境保全地 & 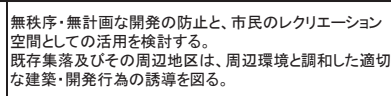 \\
\hline & & 既存住宅地 & 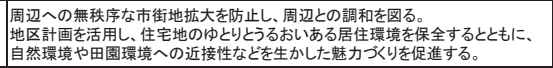 & & 既存住宅地区 & 無秩序な市街地拡大を防止し、居住環境の保全を図る。 \\
\hline & & \begin{tabular}{|l} 
集落地域整 \\
倳業地区
\end{tabular} & 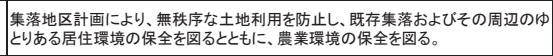 & & \begin{tabular}{|l|l|l|l|l} 
落地区計画区 \\
域
\end{tabular} & $\begin{array}{l}\text { (凡例はあるもの、区域内容を示す } \\
\text { れていない) }\end{array}$ \\
\hline & & その他 & 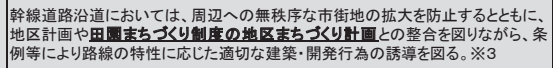 & & 幹線道 & 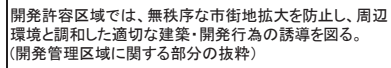 \\
\hline \multirow{4}{*}{$\begin{array}{c}\text { 地 } \\
\text { 域 } \\
\text { 斺 } \\
\text { 構 } \\
\text { 憄 } \\
※ \\
\ldots \\
1\end{array}$} & \begin{tabular}{|l|l|} 
2.加古川 \\
北地域 $\%$ \\
2
\end{tabular} & \multicolumn{2}{|c|}{ 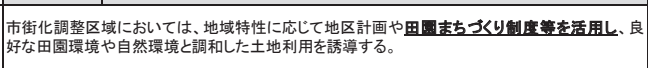 } & $\begin{array}{l}2 . \text { 加古川 } \\
\text { 北地域 } \\
2\end{array}$ & \multicolumn{2}{|c|}{ 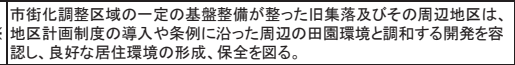 } \\
\hline & \begin{tabular}{|l|} 
7.両荘地 \\
域 22 \\
\end{tabular} & \multicolumn{2}{|c|}{ 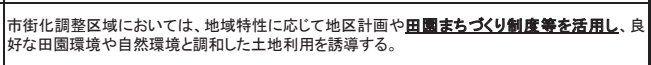 } & $\begin{array}{l}7 \text {,乘获地 } \\
\text { 域 } \% 2\end{array}$ & \multicolumn{2}{|c|}{ 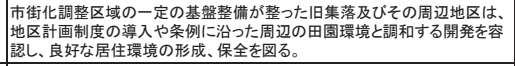 } \\
\hline & \begin{tabular}{|l|} 
8.加古川 \\
西地域 $\%$ \\
\end{tabular} & \multicolumn{2}{|c|}{ 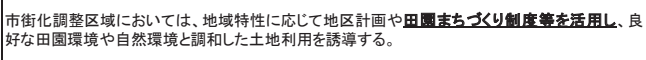 } & 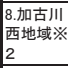 & \multicolumn{2}{|c|}{ 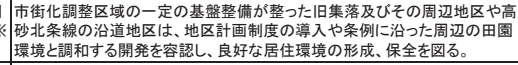 } \\
\hline & \begin{tabular}{|l|} 
9.志方地 \\
域※2
\end{tabular} & \multicolumn{2}{|c|}{ 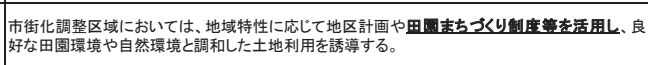 } & $\begin{array}{l}\text { 9.志方地 } \\
\text { 域 } 22 \\
\end{array}$ & \multicolumn{2}{|c|}{ 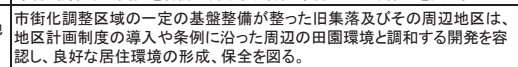 } \\
\hline
\end{tabular}


策定）では，そ 表 3 加古川市における開発許可の動向

の 4 地域を中心 に, 志方町, 平 荘町, 上荘町,

八幡町を計画の 対象区域と捉え, 全域の調整区域 を対象とせず, 市街化区域が集中する南部の調整区域を対象外としている点が, 特別指定区域制度を運用している兵庫県内の自治体の中で, 特 徵的な事例と言える（図 1)。

\section{3-2. 開発許可 · 人口の動向}

開発許可件数を表 3 に示す。許可件数は，2004 年から約 12 年間で 559 件 (約 46.6 件/年), 開発面積は 165.1 ha (約 13. 8ha/ 年) となり, その内, 調整区域の許可件数は 24 件 (2.0 件/年), 開発面積は $14.7 \mathrm{ha}$ （約 $1.2 \mathrm{ha} /$ 年）となる。また, 田園まちづく り計画の対象区域の志方町, 平荘町, 上荘町, 八幡町の開発許 可件数と開発面積は, 調整区域の許可件数と開発面積に対し, 8 件, 3.7ha と約 3 割程度となっている。

田園まちづくり計画導入以前の 2004 年からの 4 年間と, 計画 導入後の 2008 年からの 8 年間の年平均を比べると, 計画導入以前の 許可件数約 37.3 件/年, 開発面積約 16.2ha/年から, 計画導入以後 の許可件数約 51.3 件/年, 開発面積約 $12.5 \mathrm{ha} /$ 年となり, 許可件数 は増加傾向にあり, 開発面積は減少傾向にあるが, 開発圧力は依然 高いことが窥える。一方, 許可件数の内, 田園まちづくり計画の許 可件数は, 2009 年から約 7 年間の許可件数は 42 件 (6 件/年), 開発 面積は 4. 4ha（約 $0.6 \mathrm{ha} /$ 年）となり，調整区域の許可件数と開発面 積に対し, 許可件数は多く, 開発面積は小規模なことが窺える。

人口推移をみると, 田園まちづくり計画の対象区域の 4 町となる 総人口は, 29,819 人（1996 年）から 25,341 人（2014 年）となり, 減少率約 $85 \%$ となっている。 4 町の中で最も人口が減少している上荘 町は, 減少率約 79.7\%となっている。一方, 唯一人口が増加してい る八幡町は, 増加率約 $110 \%$ となるが, 前述の開発許可状況を踏まえ ると, 必ずしも田園まちづくり計画の許可件数が，人口増加を促す ことには結びついていないことを示している(図 2)。

3-3. 兵庫県・加古川市における特別指定区域制度のメニュ一比較 兵庫県では, 2002 年の特別指定区 域制度の創設後, 9 種類の用途型と 4 種類の目的型を運用していたが,「制 度創設からの運用の中で, 調整区域 における多様な集落特性や, 六次産 業等地域資源を活用した産業の創出 や沿道の保全と利活用による地域の 活性化等の特色あるまちづくりの取 組に的確に対応することが困難であ る等の課題 ${ }^{(8)} 」$ から, 2015.4.1に 9 種類の目的型に統合・再編する等の 見直しを行った。計画・運用主体に よって, 区域メニューの活用方法に 違いがあり, 地元自治会等によるま

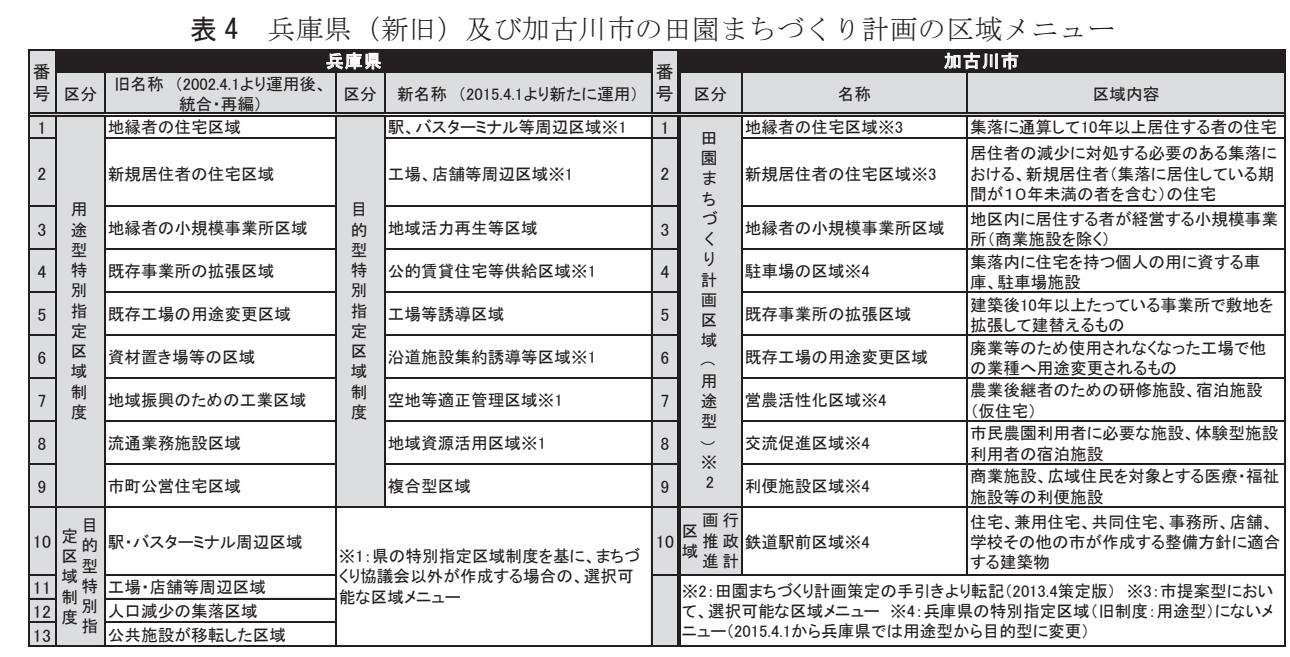

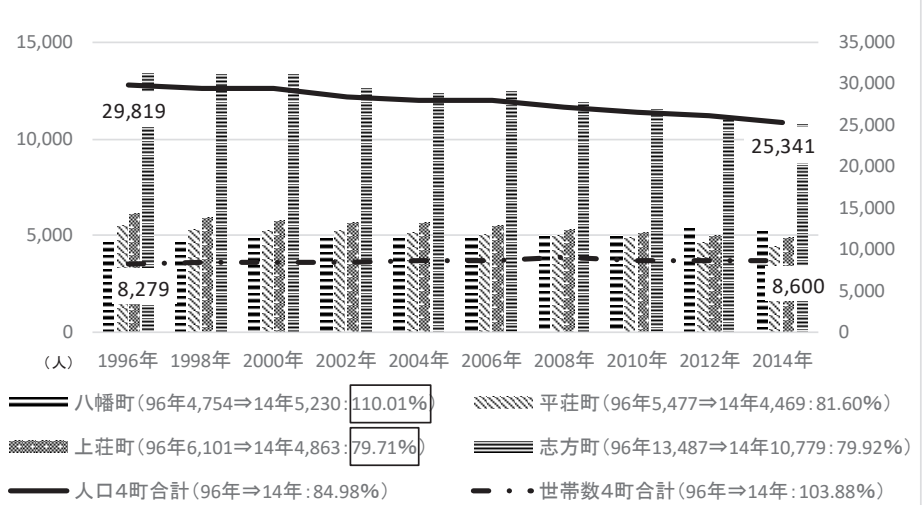

図 2 田園まちづくり計画の対象区域における人口推移

ちづくり協議会では, 番号 1 から 9 までの区域メニューが可能とな るが, まちづくり協議会以外が作成する市町の土地利用計画 (以下, 市提案型) では, 1, 2, 4, 6, 7, 8 の 6 つの区域メニューに限られる（表 4)。

加古川市の田園まちづくり計画の構成は, 田園まちづくりに関す る方針を示し, 方針に即して土地利用計画を定め, 土地利用計画の 実現に向けた, 区域メニューを決定する。また, 10 の区域メニュー が用いられ，一部兵庫県（2015.4.1 以前）の用途型とも重なるが, 独自の区域メニューとして, 駐車場の区域, 営農活性化区域, 交流 促進区域，利便施設区域，鉄道駅前区域が設けられている（表 4)。 利便施設区域では, 商業施設, 医療・福祉施設等の施設を対象とし, 指定地区の住民とともに, 広域住民を対象としていることから, 計 画の指定地区周辺への影響が懸念される。また, まちづくり協議会 と市提案型を併用運用しており, 市提案型では, 地元自治会等への 働きかけにより, 協議会設立までの機運が低い地区に指定し, 区域 メニューは地縁者の住宅区域と新規居住者の住宅区域の 2 つの区域 
メニューに限られ, 兵庫県の 6 つの区域メニューに比べて選択肢が 少ない。

\section{4. 田園まちづくり計画の指定地区と開発実態}

\section{4-1. 田園まちづくり計画の指定地区の状況}

計画の指定地区の状況は, 29 地区が計画認定と田園まちづくり計 画の区域指定を受けており，その内，まちづくり協議会を中心とす る地区（以下，まちづくり協議会型）として 19 地区，市提案型とし て 10 地区となる（図 3）。活用している区域メニューとして，地縁 者の住宅区域が 29 地区全て, 新規居住者の住宅区域が 23 地区, 地 縁者の小規模事業所区域が 3 地区, 既存事業所の拡張区域が 2 地区, 利便施設区域が 1 地区となり，10の区域メニューの内，5つの区域 メニューとなり，指定地区における区域メニューの多様化が進んで いる（表 5)。まちづくり協議会型では，2007 年度の高畑地区，薬栗 地区を指定し（図 3，凡例 $1 \cdot 2$ ），その後，2014 年を除き，毎年地 区が追加され，特に，八幡町の既存集落では大部分が指定されてい るとともに, 2010 年度より市提案型として, 人口減少や空き家・空 き地対策に限定した田園まちづくり計画を提案し，簡易な手続きで 計画策定するもので, 10 地区が指定されており, 地縁者の住宅区域, 新規居住者の住宅区域の運用を行っている。特に志方町に多く位置 することが分かる(図 3)。田園まちづくり計画の対象区域の志方町, 平荘町, 上荘町, 八幡町の既存集落地の殆どが指定され，指定面積 は 3, 674. 5ha となり, 対象区域の 4 町 (6,526ha)の約 $56.3 \%$ となる。 しかし,まちづくり協議会型では, 当初指定された薬栗地区を始め, 許可実績が無い地区が 6 地区存在している。実績が無い地区が存在

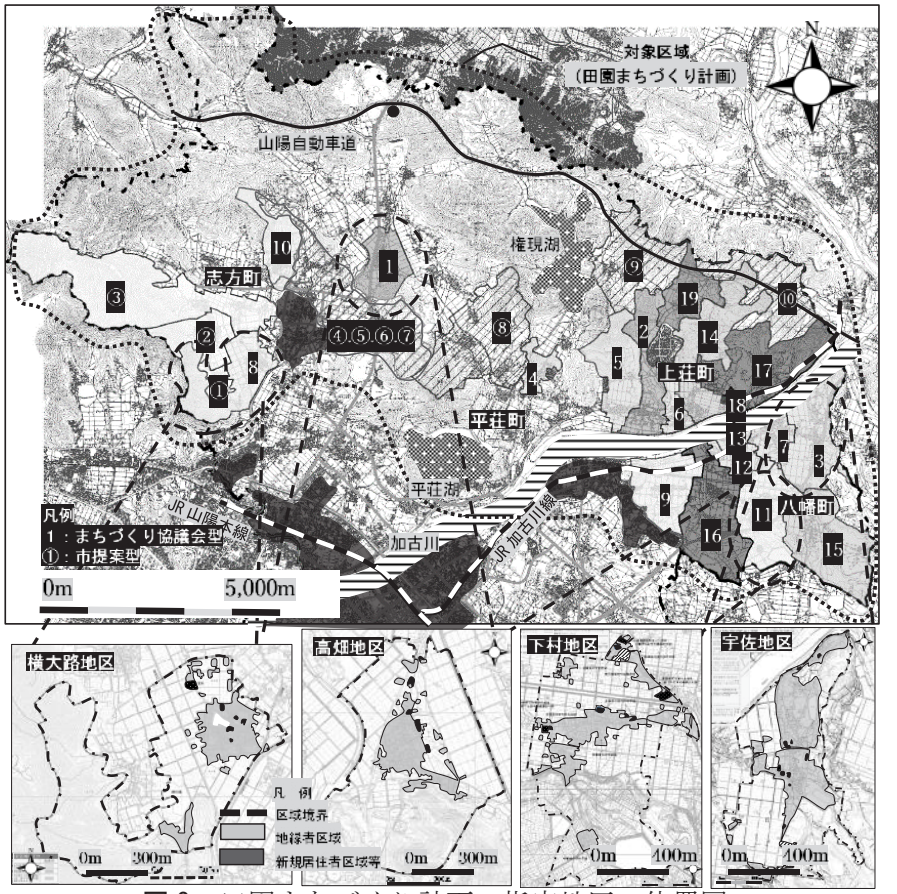

図 3 田園まちづくり計画の指定地区の位置図

する一方, まちづくり協議会による発意で, 10 地区が指定内容の変 更を行っており，運用に差が生じ始めている（表 5)。

\section{4-2. 田園まちづくり計画の指定地区におけるケーススタディ}

指定地区のケーススタディとして, まちづくり協議会型の 19 地区 に着目し, 田園まちづくり計画の指定内容の変更を行っている 10 地区の内, 複数の区域メニューを運用するとともに, 申請件数が多

表 5 加古川市田園まちづくり計画の指定地区の現況

\begin{tabular}{|c|c|c|c|c|c|c|c|c|c|c|c|c|c|c|c|}
\hline 理別 & & & & & & & まちつくり㔹 & 撞会提军 & & & & & & & \\
\hline 整理番号(図3の凡例に準じる) & 1 & 2 & 3 & 4 & 5 & 6 & 7 & 8 & 9 & 10 & 11 & 12 & 13 & 14 & 15 \\
\hline 地区名 & 高畑地区 & 薬栗地区 & 宗佐地区 & 神木地区 & 小野地区 & 都染地区 & 国包地区 & $\begin{array}{c}\text { 横大路地 } \\
\text { 区 } \\
\end{array}$ & \begin{tabular}{|c|} 
中西条地 \\
区
\end{tabular} & 西中地区 & 下村地区 & 船町地区 & 厄神地区 & \begin{tabular}{|c|} 
見土呂地 \\
区
\end{tabular} & 野村地区 \\
\hline \begin{tabular}{|l|} 
地区まちづくり認定年度 \\
地区まちづくり証定日
\end{tabular} & 2007 & 年度 & & 2008 & 年度 & & & & 2009 & 9年度 & & & 年度 & & 1 年度 \\
\hline $\begin{array}{l}\text { 地区まちつうくり認定日 } \\
\text { 田園まちつうくり䧕指定日 }\end{array}$ & 2008 年 & 3 月13日 & & 2009年 & 3月4日 & & & & $\begin{array}{l}2010 \text { 年 } \\
2010 \text { 年 }\end{array}$ & $\begin{array}{l}5 \text { 月8日 } \\
\text { 4月8日 }\end{array}$ & & 2011年3 & 3月14日 & 2012 年 & 年2月6日 \\
\hline 崮園まちうくくり計画区域変更回数 & $\frac{2008 \text { 年 }}{3}$ & 4月7日 & 4 & 2009年 & 4月17日 & & 2 & 1 & 20 & $\begin{array}{c}\text { en月8日 } \\
1\end{array}$ & 2 & 1 & 5月9日 & 2012年 & 毛4月19日 \\
\hline 田園まちづくり計画区域メニュー ※1 & (1) $\cdot(2)$ & (1).(2) & (1) $\cdot(2) \cdot(3) \cdot(5)$ & (1) $\cdot(2)$ & (1) $\cdot(2)$ & (1) $\cdot(2)$ & (1) $\cdot(2)$ & (1).(2) & $(1) \cdot(2)$ & $(1) \cdot(2)$ & $(1) \cdot(2) \cdot(5)$ & $(1) \cdot(2)$ & $(1) \cdot(2)$ & (1):(2):(3) & (1) $\cdot(2)$ \\
\hline 補助金活用 ※2 & & & & & & $\star$ & & $\star$ & & & & & & & \\
\hline アドバイザー派遣制度活用 ※2 & & & & $\star$ & & $\star$ & & $\star$ & & & & & & & \\
\hline 田園まちづくり計画区域面積(ha) & 88.8 & 119.2 & 148.0 & 38.5 & 131.0 & 45.0 & 48.0 & 150.0 & 126.8 & 90.8 & 149.6 & 44.1 & 16.8 & 183.0 & 202.0 \\
\hline 指 地縁者の住宅区域面積 $\left(\mathrm{m}^{2}\right)$ & $115,000.0$ & $169,000.0$ & $579,000.0$ & $74,000.0$ & $128,000.0$ & $116,000.0$ & $272,000.0$ & $223,000.0$ & $159,000.0$ & $109,000.0$ & $261,000.0$ & $147,000.0$ & $72,000.0$ & $157,000.0$ & $225,000.0$ \\
\hline 区 新規居住者の住宅区域面積 $\left(\mathrm{m}^{2}\right)$ & $3,195.0$ & 410.0 & $7,368.0$ & $1,625.0$ & $3,576.0$ & $1,218.0$ & $7,366.0$ & $4,234.0$ & $2,780.0$ & $1,502.0$ & $2,798.0$ & $2,224.0$ & $3,037.0$ & $4,436.0$ & $4,411.0$ \\
\hline 域地縁者の小規模事業所区域面積 $\left(\mathrm{m}^{2}\right)$ & & & 839.0 & & & & & & & & & & & $2,262.4$ & \\
\hline $\begin{array}{l}\text { 㢸 } \\
\text { 既存事業所の掂張区域面積 }\left(\mathrm{m}^{2}\right)\end{array}$ & & & $10,760.3$ & & & & & & & & $5,893.6$ & & & & \\
\hline 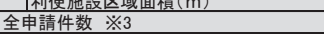 & 6 & & 5 & 2 & & 1 & 5 & 4 & 1 & 2 & 7 & 1 & & 1 & 2 \\
\hline 全申請面積 $\left(\mathrm{m}^{2}\right) \quad ※ 3$ & $2,415.3$ & & $12,256.3$ & 866.0 & & 544.7 & $1,981.4$ & $1,232.9$ & 187.4 & 688.1 & $8,370.8$ & 308.1 & & 440.0 & 727.4 \\
\hline 人口 $($ 人) $※ 4$ & 369 & 527 & 615 & 150 & 320 & 456 & 711 & 576 & 512 & 341 & 949 & 304 & 256 & 428 & 508 \\
\hline 世帯数 ※4 & 120 & 180 & 258 & 55 & 127 & 122 & 236 & 221 & 182 & 119 & 260 & 113 & 85 & 149 & 143 \\
\hline 過去最大人口 $($ 人) & 498 & 682 & 779 & 221 & 416 & 563 & 923 & 638 & 650 & 526 & 1,054 & 355 & 335 & 511 & 657 \\
\hline (最大年) & 1987年 & 1985年 & 2005年 & 1987年 & 1980年 & 1975年 & 1977年 & 1999年 & 1993年 & 1979年 & $\begin{array}{c}(1996 \text { 年: } \\
1999 \text { 年 })\end{array}$ & 2001年 & 1977年 & 1975年 & 1981年 \\
\hline 種别 & & まちこ & 《以協倳会提家弄 & & & & & & 市提 & 家型 & & & & & 合計 \\
\hline 也区まちづくり認定年度 & 2012 & 年度 & 2013年度 & 15年度 & & 2010年度 & & & 2011 & 年度 & & & 2014年度 & & \\
\hline 地区まちづくり認定日 & 2013年 & 2月14日 & 2014年2月4日 & 2016年1月28日 & & 011 年6月 10 & & & 2012年3 & 3月30日 & & & 14 年7月22 & & \\
\hline 田園まちづくり計画区域指定日 & 2013年 & 4月23日 & 2014年3月13日 & 2016年3月29日 & & 011 年7月 13 & & & 2012年5 & 5月17日 & & & 14年 10 月 15 & & \\
\hline 田園まちづくり計画区域変更回数 & 2 & & 1 & & & & & & & & & & & & 19.0 \\
\hline 田園まちづくり計画区域メニュー ※1 & $\begin{array}{l}\text { (1). (2) } \\
\text { (3.9) }\end{array}$ & (1) (2) & (1) (2) & (1) & (1) & (1) & (1) (2) & (1). (2) & (1) (2) & (1) & (1) (2) & (1) (2) & (1) & (1) & \\
\hline 補助金活用 ※2 & & & & & & & & & & & & & & & 2 \\
\hline アドバイザー派遣制度活用 ※2 & & & & & & & & & & & & & & & 3 \\
\hline 田園まちづくり計画区域面積 (ha) & 198.0 & 214.4 & 9.8 & 84.4 & 33.9 & 113.2 & 504.0 & & 305 & 5.6 & & 274.5 & 187.8 & 167.3 & $3,674.5$ \\
\hline 指 地縁者の住宅区域面積 $\left(\mathrm{m}^{2}\right)$ & $306,000.0$ & $140,000.0$ & $40,000.0$ & $46,000.0$ & $45,000.0$ & $164,000.0$ & $242,000.0$ & $36,000.0$ & $204,000.0$ & $97,000.0$ & $151,000.0$ & $391,000.0$ & $78,000.0$ & $15,000.0$ & $4,761,000.0$ \\
\hline 揎 新規居住者の住宅区域(箇所) & 7 & 8 & 1 & & & & & & 4 & & 4 & 2 & & & 106 \\
\hline 区定 新規居住者の住宅区域面積 $\left(\mathrm{m}^{2}\right)$ & $12,802.0$ & $3,939.0$ & 310.0 & & & & $1,036.0$ & 300.8 & 818.4 & & 798.0 & 444.3 & & & $70,628.4$ \\
\hline 域地縁者の小規模事業所区域面積 $\left(\mathrm{m}^{2}\right)$ & $1,751.5$ & & & & & & & & & & & & & & 4.852 .9 \\
\hline 毎既存事業所の拡張区域面積 $\left(\mathrm{m}^{2}\right)$ & & & & & & & & & & & & & & & $16,653.9$ \\
\hline 每利便施設区域面積 $\left(\mathrm{m}^{2}\right)$ & $5,400.0$ & & & & & & & & & & & & & & $5,400.0$ \\
\hline 全申請件数 ※3 & 1 & & & & & & 1 & 1 & 1 & & & 1 & & & 42 \\
\hline 全申請面積 $\left(\mathrm{m}^{2}\right) \quad ※ 3$ & $5,396.8$ & & & & & & 935.1 & 614.9 & & & & 930.4 & & & $38,821.1$ \\
\hline 人口 $($ 人) $※ 4$ & 835 & 257 & 90 & 79 & 131 & 346 & 702 & 529 & 1,448 & 236 & 363 & 1,199 & 147 & 41 & 13,425 \\
\hline 世帯数 ※4 & 221 & 74 & 30 & 29 & 40 & 95 & 226 & 189 & 417 & 96 & 146 & 456 & 54 & 11 & 4,454 \\
\hline 過去最大人口 (人) & 954 & 327 & 110 & 113 & 166 & 469 & 922 & 758 & 1,720 & 465 & 638 & 1,871 & 210 & 60 & 17,591 \\
\hline (最大年) & 2002年 & 1999年 & 1977年 & 1975年 & 1987年 & 2000年 & 1994年 & 1979年 & 1994年 & \begin{tabular}{|c|} 
(1979年· \\
1981年)
\end{tabular} & 1981年 & 1982年 & 1975年 & $\begin{array}{c}(1979 \text { 年· } \\
1981 \text { 年) }\end{array}$ & \\
\hline
\end{tabular}


表 6 指定地区のケーススタディの現況

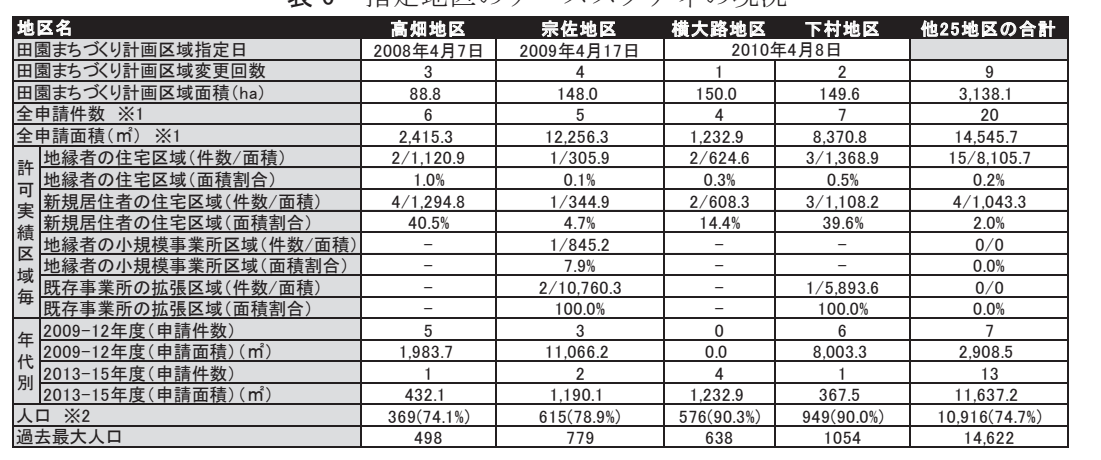

表 7 指定内容, 区域メニューの変更動向

\begin{tabular}{|c|c|c|c|c|}
\hline ※1 & 回数 & 変更時期 & $※ 2$ & ※3 \\
\hline \multirow{3}{*}{ A } & 1回目 & 2009.6 .11 & (2) & 当初 $1 \Rightarrow 2$ 追加箇所: 計 3 箇所 \\
\hline & 2回目 & 2011.7 .11 & (2) & 当初 $3 \Rightarrow 1$ 追加箇所 : 計 4 箇所 \\
\hline & 3回目 & 2014.5 .26 & (2) & 当初 $4 \Rightarrow 1$ 追加箇所: 計5箇所 \\
\hline \multirow{4}{*}{$\mathrm{B}$} & 1回目 & 2010.5 .20 & (2) & 当初 $6 \Rightarrow 4$ 追加箇所: 計 10 箇所 \\
\hline & 2回目 & 2011.7 .13 & (5) & \multirow{2}{*}{$10,760.29 \mathrm{~m}^{2}$ 追加 (当初 $0 \mathrm{~m}^{2}$ ) } \\
\hline & 3回目 & 2012.7 .5 & (5) & \\
\hline & 4回目 & 2013.7 .5 & (3) & $838.99 \mathrm{~m}^{2}$ 追加 (当初 $\left.0 \mathrm{~m}^{2}\right)$ \\
\hline c & 1回目 & 2014.8.14 & (1) $\cdot(2)$ & $\begin{array}{l}\text { (1): 当初 } 4 \Rightarrow 1 \text { 追加箇所: 計5箇所 } \\
\text { (2): } 524 \mathrm{~m}^{2} \text { 追加: 計22.3ha }\end{array}$ \\
\hline \multirow{2}{*}{ D } & 1回目 & 2011.7 .11 & (2) & 当初 $4 \Rightarrow 1$ 追加箇所 : 計5箇所 \\
\hline & 2回目 & 2012.7 .5 & $(5)$ & $5,893.63 \mathrm{~m}^{2}$ 追加 $\left(\right.$ 当初 $\left.0 \mathrm{~m}^{2}\right)$ \\
\hline
\end{tabular}

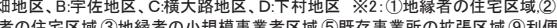
施設区域 ※3: 各区域におけ增加面積。新規居住者は追加䇢所数を記載

画区域の指定以降，全指定地区の中で最も多い(表 6 ・

く，アドバイザーの派遣や補助金の活用を考慮し，高畑地区，宗佐

地区，横大路地区，下村地区を抽出する（表 $5 \cdot 6$ ）。

\section{4-2-1. 高畑地区}

高畑地区において, 全 29 指定地区の中で, 最も多い 4 件の新規居 住者の住宅区域における許可実績と 2 件の地縁者の住宅区域の計 6 件が申請, 許可された。また, 計画区域の指定以降, 指定内容を 3 度変更しており，宇佐地区に次いで多く，変更内容では，全て新規 居住者の住宅区域の追加で, 当初 1 箇所から空き家等 4 箇所増加し, 現在 5 箇所となり (図 4), 新規居住者の住宅区域における申請, 許 可が，全地区の中で最も多い理由と考えられる(表 $6 \cdot 7$ )。新規居住 者の住宅区域の追加理由と

\section{して ${ }^{(9)}$, 地権者から所有地} を売却するため, 新規居住 者の住宅区域に指定して欲 しい旨の申出を受け, まち づくり協議会での検討を行 った上で市へ指定変更の申 請がなされた。他の 3 地区 と違い，まちづくりに関す る方針の目標・テーマの一 部に,「地域の人と外から来 る人が気軽に向き合い,つ ながりを活かした開かれた むらづくりを行っていく (10)」から，新規居住者を 積極的に受け入れる意思が 窥え，方針に即しており， また, 追加された区域では, 新規居住者の住宅建設が進 んでいる(写真 1$) 。$

\section{4-2-2. 宇佐地区}

宇佐地区において, 全 29 指定地区の中で, 最も複数 の区域メニューの申請, 許 可を受け, 地縁者の住宅区 域と新規居住者の住宅区域, 地縁者の小規模事業所区域 の各 1 件, 既存事業所の拡 張区域が 2 件の計 5 件が申 請, 許可された。また, 計

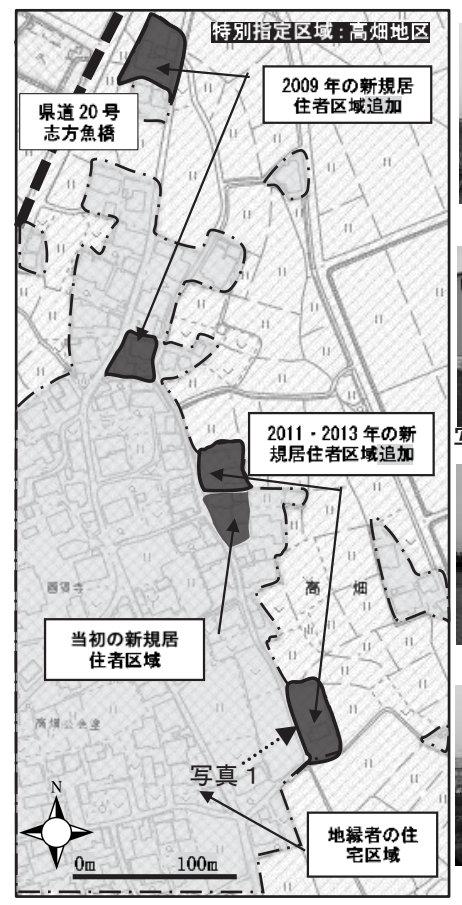

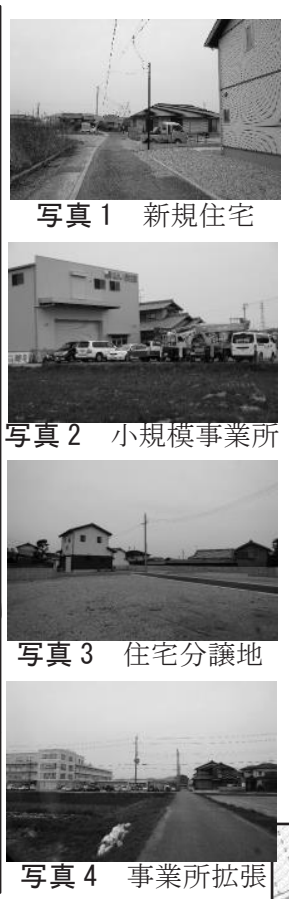
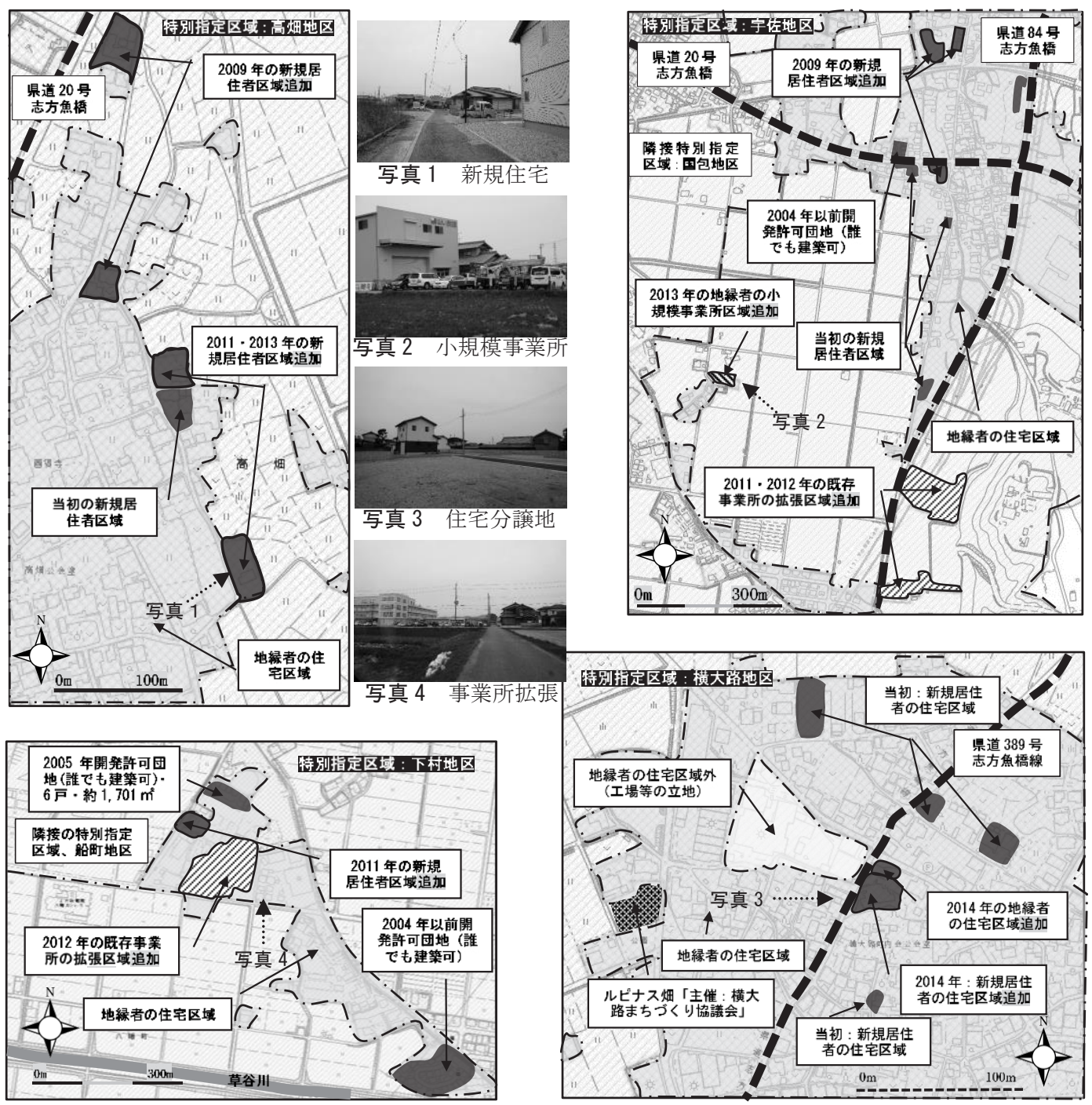

図 4 指定地区のケーススタディ 
において各 2 , 計 4 件が申請, 許可されており, また, 計画区域の 指定以降, 指定内容を 1 度変更している(表 $6 \cdot 7$ )。変更内容では, 新規居住者の区域の追加で, 当初 4 箇所から空き家等, 1 箇所増加 し, 現在 5 箇所となっており, 隣接地の地縁者の住宅区域とともに 追加した（図 4)。新規居住者の住宅区域の追加理由として ${ }^{(9)}$, 事 業者からまちづくり協議会及び市一, 所有地を住宅用地として販売 したいとの相談があり，検討の結果，地域の活性化に資すると判断 し，市が指定変更の手続きを進めた。現在，その追加指定された区 域では, 分譲住宅が許可されている。しかし, 2014.8 月に追加以降, 5 区画中 2 区画の夕の販売となっている (写真 3$)$ 。その要因として, 既存集落のほぼ中心に位置し，周囲を地縁者区域に指定されている ことから, 地区外の居住者が敬遠 ${ }^{(9)}$ していると考えられが，田園 まちづくり計画策定時の地元住民のアンケートでは, 約 8 割の方が 地区外から新たな居住者の移り住みを希望しているが (10)，反した 状況となっている。一方，まちづくり協議会では，緑化活動や清掃 や活動等を目的に，市の補助金やアドバイザー派遣制度を活用して いる。緑化活動として，まちづくり協議会が主体となり，まちづく り構想において「眺望の良い場所 ${ }^{(10)} 」 に$ 設定している付近の休耕 田を利用して、ルピナスを世話している。

\section{4-2-4. 下村地区}

下村地区において, 全 29 指定地区の中で, 最も多い計 7 件の申請, 許可がなされ, 地縁者の住宅区域と新規居住者の住宅区域の各 3 件, 1 件の既存事業所の拡張区域における申請, 許可となっている。ま た, 計画区域の指定以降, 指定内容を 2 度変更している (表 $6 \cdot 7$ )。 変更内容では, 新規居住者の区域の追加で, 当初 4 箇所から空き家 等, 1 箇所増加し, 現在 5 籄所と既存事業所の拡張区域を新たに 1 箇所追加した（図 4)。計画の策定過程に発行され，田園まち通信 VOL. 9 に記載された「地縁者の住宅区域の物件売却を検討される際 は，協議会に相談 ${ }^{(10)} 」 に$ 即し，地権者から所有地を売却するため， 新規居住者の住宅区域に指定して欲しい旨の申出を受け，まちづく り協議会での検討を行った上で市へ指定変更の申請があった。また, 当初まちづくり構想において, 位置づけが無いゾーン ${ }^{(10)}$ に既存事 業所の拡張区域を追加し, 病院が拡張されている(写真 4 )。

\section{5. まとめ}

(1)田園まちづくり計画の実態と課題

田園まちづくり計画の対象区域として, 調整区域の全域ではなく, 市北部を対象とし, 都市マスにおいて明確に位置づけられている(11) そのことで, まちづくり協議会型を主体に, 2007 年度の 2 地区から， その後, 19 地区とともに, 2010 年度から市提案型の運用により, 市 北部の対象区域としての集落地をほぼ網羅していることが明らかに なった。さらに, 各地区の現状に即寸る形で 10 の区域メニューが用 意され，当初 2 つから 5 つの区域メニューの活用に広がり，また， 2009 年度の申請件数 3 件から年平均 6 件に着実に実績が伸びている ことが明らかになった。田園まちづくり計画の効果について，人口 減少には必ずしも効果があると言えないが，一概に評価することは 難しい。一方, 運用当初の 2007 年度の薬栗地区を始め, 実績がない 地区がまちづくり協議会型の 6 地区（市提案型 7 地区）存在してい ることから，現行の支援制度として，補助金やアドバイザー派遣制 度及び田園まちづくり計画の指定地区における「空き家・空き地」
情報サイト等の支援制度の検証とともに，指定内容の見直しを含め た対応策が必要と考える。

(2)まちづくり協議会型の運用実態と効果

指定内容の変更について, 高畑地区の 2009 年 6.11 に指定内容の 変更後, 10 地区 19 回の指定内容の変更（表 5・2016.3.1 現在）が 行われ, 田園まちづくり計画が機能し, まちづくり協議会での検討 を踏まえ指定内容の変更がなされたため, 継続的な計画運用が行わ れていると言える。さらに, 市提案型からまちづくり協議会型への 移行相談 ${ }^{(9)}$ があり, 地元住民の田園まちづくり計画に対する効果 が見受けられる。

指定当初に描いていたまちづくり構想や地元住民の意向に即寸る 内容や当初に描いた内容とは異なる場合でも，まちづくり協議会に おいて検討を行った上で, 指定内容を変更しており, PDCA が機能し ている。一方, 相談内容を前提に变更しているため, 相談内容の有 無に関わらず，指定地区において不必要な立地はないか，また，宅 地と農地の混在などの土地利用となっていないか等の定期検証を行 い, 運用することが期待される。また, 横大路地区のように, 指定 内容を変更したにも関わらず，想定した成果が出ない事例もあり， 専門家を含めた検証や指定内容の変更基準等の整備が望まれる。最 後に，下村地区のように，事前にまちづくり協議会に相談がなされ るため, 地元への事前周知により, 未然の紛争解決に繋がると考え られる。

\section{【謝辞】}

最後に, 研究に際し多大な御協力を頂きました, 加古川市都市計画部都市 計画課にはこの場をお借りして御礼を申し上げます。

\section{【補注】}

（1）地元住民が中心となり協議会を発足し，市長に届出・認定を受ける。

（2）加古川市では特別指定区域制度を田園まちづくり制度と呼称とする。 (3²） 1980 年度及び 2015 年度都市計画年報の記載に基づき, 2015.3 月末時 の值である。

（5）２０10 年度国勢調査に基づき算出した值である。

(6〜7) 加古川市都市M P (平成 23 年 4 月）より一部転記した。

（8）兵庫県 H P の特別指定区域制度より一部転記した。

(9) 市担当者へのヒアリングによる。

（10）田園まちづくり計画のまちづくりに関する方針, 土地利用計画, まち づくり構想, 各指定地区のまちづくりニュース等より一部転記した。

（11）改定作業中の都市マスにおいても，継続運用の予定となっている。

\section{【参考文献】}

1）難波健, 生島一明, 黒原義晶, 谷川順彦, 安田丑作:「特別指定区域制度」 の拡充と今後の展開 兵庫県における市街化調整区域の土地利用調整・管理 と開発許可制度の運用に関する研究 (その 3 ), 日本建築学会技術報告集 No. 25 , pp.263-266, 2007.6

2）難波健，谷川順彦，福永聡，田中一樹，安田丑作：「特別指定区域制度」 の運用実態からみた市街化調整区域における都市的土地利用の諸課題 兵庫 県における市街化調整区域の土地利用調整・管理と開発許可制度の運用に関 する研究 (その 4 ), 日本建築学会技術報告集 No. 26, pp.781-784, 2007.12 3）垣内俊宏, 姥浦道生, 難波健 : 市街化調整区域における開発許可条例の運 用実態と課題に関する研究一兵庫県小野市における特別指定区域制度の運用 を事例として一，都市計画論文集 45-3 号，pp.739-744，2010.10 4）浅野純一郎, 熊野稔: 開発許可条例による市街化調整区域の土地利用マネ ジメントに関するー考察〜兵庫県加古川市を対象として〜， 日本建築学会大 会学術講演梗概集 (北陸), pp.49-52, 2010.9

[2017 年 2 月 1 日原稿受理 2017 年 4 月 1 日採用決定］ 